\title{
EFFECT OF UROTENSIN I ON THE IONIC CONTENT OF THE PLASMA AND THE GALLBLADDER BILE OF Hoplias malabaricus (Bloch, 1794) (Teleostei, Characiformes, Erythrinidae)
}

\author{
Bernardo Baldisserotto and Roni João Rakoski \\ Departamento de Fisiologia - Centro de Ciências da Saúde \\ UFSM, Santa Maria, RS \\ Olga Martins Mimura \\ Departamento de Fisiologia - Instituto de Biociências \\ USP, São Paulo, SP
}

\section{RESUMO}

Este estudo investigou o efeito da urotensina I (UI) na composição iônica do plasma e da bile vesicular (BV) de Hoplias malabaricus, um teleósteo dulciaquaicola. A ação deste hormônio no transporte de água na vesícula biliar também foi analisada. Os peixes foram capturados em açudes situados no campus da Universidade Federal de Santa Maria (UFSM), Santa Maria, RS. O sangue foi coletado por punção da artéria caudal e a BV drenada pelo ducto cístico. A injeção intraperitoneal de UI (500 ng/kg) em H. malabaricus aumentou os niveis de $\mathrm{Na}^{+}$no plasma e na $\mathrm{BV}$ em relação ao grupo injetado com salina. Contudo, a injeção deste neuro-hormônio não alterou os niveis de $\mathrm{K}^{+}, \mathrm{Ca}^{++} \mathrm{e}$ $\mathrm{Mg}^{++}$no plasma e na BV. A vesícula billiar de $H$. malabaricus apresenta um fluxo de água mucosa-serosa. $A$ incubação de sacos da vesícula biliar com UI (10-8 $\mathrm{M})$ aumentou significativamente o fluxo de água. Como a Ul altera os níveis de $\mathrm{Na}^{+}$ na BV e o fluxo de água na vesícula biliar, é possivel que a UI participe da regulação da composição da bile de peixes. 


\section{SUMMARY}

In this study the urotensin I (UI) effect on the ionic content of the plasma and the gallbladder bile (GB) of Hoplias malabaricus, a freshwater teleost, was investigated, and the action of this hormone on the water transport in the gallbladder was analyzed. Fishes were captured in ponds situated on the campus of the Federal University of Santa Maria (UFSM), Santa Maria, Southern Brazil. Blood was collected by puncture of caudal artery and GB was drained by the cystic duct. The intraperitoneal injection of UI $(500 \mathrm{ng} / \mathrm{kg})$ in $\mathrm{H}$. malabaricus increased the $\mathrm{Na}^{+}$levels in the plasma and in the GB in relation to the saline-injected group. However, no change was observed in the levels of $\mathrm{K}^{+}, \mathrm{Ca}^{++}$and $\mathrm{Mg}^{++}$in the plasma and in the GB when UI was injected. The gallbladder of $H$. malabaricus has a mucosa-serosa water flow. On incubation of the serosa of the gallbladder sacs with $\mathrm{UI}\left(10^{-8} \mathrm{M}\right)$ there was a significant increase in water flow. Due to the fact that $\mathrm{UI}$ alters the GB $\mathrm{Na}^{+}$levels and the water flow in the gallbladder, it is possible that $\mathrm{UI}$ can be involved in the regulation of the bile composition on fishes.

\section{INTRODUCTION}

Among several physiological activities attributed to the caudal neurosecretory system, the control of osmoregulatory organs (by both direct and indirect routes) has been the main field of investigation (Bern, 1985). Studies on the "in vivo" effects had reported that injection of urophysial extracts or semipurified urotensin I (UI) and urotensin II (UII) in fish have produced changes in the plasma ionic concentration (Fryer et al., 1978; Bern and Nishioka, 1979; Woo et al., 1980; Mimura, 1988; Baldisserotto et al., 1994). Urophysectomy, on the other hand, has produced contradictory results (Fryer et al., 1978; Bern and Nishioka, 1979; Baldisserotto et al., 1994).

Mimura and Baldisserotto (1989) have verified that urophysial extract alters the transport of ions and water in the gallbladder of Synbranchus marmoratus. However, there are no studies relating the effect of the caudal neurosecretory system on the ionic concentration of the gallbladder bile (GB) of 
teleosts. In this study the $\mathrm{Ul}$ effect on the ionic content of the plasma and the GB of Hoplias malabaricus, a freshwater teleost, was investigated, and the action of this hormone on the water transport in the gallbladder was analyzed.

\section{MATERIAL AND METHODS}

Specimens of Hoplias malabaricus were captured with nets placed in ponds situated on the campus of the Federal University of Santa Maria (UFSM), Santa Maria, Southern Brazil. Specimens were maintained in fasting during 3 days (Baldisserotto et al., 1990a). Fishes were divided in three groups: control (uninjected), Ul-injected (500 ng/kg)(Sigma), and saline-injected. All injections were intraperitoneal and fish were sacrificed $2 \mathrm{~h}$ after the injections. Plasma and GB samples were obtained as described by Baldisserotto et al. (1990b). Briefly, fishes were stunned with a blow on the head and blood was collected by puncture of caudal artery and centrifuged at $2000 \mathrm{rpm}$ for $5 \mathrm{~min}$. After blood collection, the abdomen was opened and the gallbladder was carefully isolated from the surrounding organs. GB was drained by the cystic duct. Samples of plasma and $\mathrm{GB}$ and were stored $\left(-10^{\circ} \mathrm{C}\right)$ until analysis. Methods for ion analysis have been previously described (Mimura and Baldisserotto, 1988).

In another set of experiments, the water flow in the gallbladder was analyzed by the method used by Baldisserotto et al. (1993). The water flow was expressed as $\mu \mathrm{l}$ of water transferred from mucosa to serosa in function of the gallbladder weight during $1 \mathrm{~h}$ ( $\mu \mathrm{l} / \mathrm{g}$ tissue.h). The Ringer-bicarbonate solution contained (in mM): $\mathrm{NaCl} 120.0 ; \mathrm{KCl} 5.5 ; \mathrm{MgSO}_{4} .7 \mathrm{H}_{2} \mathrm{O}$ 1.45; $\mathrm{CaCl}_{2} .2 \mathrm{H}_{2} \mathrm{O} 3.0$; $\mathrm{NaHCO}_{3}$ 10.0; glucose 2.5; adjusted to $\mathrm{pH} 7.0$ with $\mathrm{HCl}$. Gallbladder sacs were incubated in the presence or absence of $\mathrm{UI}\left(10^{-8} \mathrm{M}\right)$ on the serosa.

Comparisons of ion levels of the GB and plasma of the different groups were assessed using one-way analysis of variance and Student-NewmanKeuls test. To verify the slynificance of water flow in the gallbladder and difference between means (control and UI), the Student-t test was used. All test were done using the software Microstat (Ecosoft, Inc.). All values were expressed as mean \pm $\mathrm{SE}$, and the minimum significant level was $p<0.05$. 


\section{RESULTS}

The injection of UI has increased the plasma $\mathrm{Na}^{+}$levels in relation to the saline-injected group, and the injection of saline has increased the plasma $\mathrm{Na}^{+}$levels when compared to the control group. The injection of $\mathrm{UI}$ has also increased the GB Na+ levels when compared to the saline-injected group, but this one have not changed the GB Na+ levels in relation to the control group. The treatment with $\mathrm{UI}$ did not change the plasma $\mathrm{Ca}^{++}$levels when compared to the saline treatment, while injection of saline have increased the plasma $\mathrm{Ca}^{++}$levels of the plasma in relation to the control group. The injection of UI did not change the $\mathrm{GB} \mathrm{Ca}^{++}$levels in relation to the saline-injected group. Nevertheless, the injection of saline has increased the $\mathrm{GB} \mathrm{Ca}^{++}$levels in relation to the control group (figure 1). $\mathrm{UI}$ and saline injections did not change the $\mathrm{GB}$ and plasma $\mathrm{K}^{+}$and $\mathrm{Mg}^{++}$levels (figure 2).

The gallbladder of $H$. malabaricus has a water flow from the mucosa to serosa $(43.99 \pm 15.28 \mu \mathrm{l} / \mathrm{g}$ tissue. $h, n=4)$. Incubation of gallbladder sacs serosa with $U I\left(10^{-8} M\right)$ increased significantly $(p<0.05)$ the water flow $(407.75 \pm 106.58$ $\mu \mathrm{l} / \mathrm{g}$ tissue. $\mathrm{h}, \mathrm{n}=6)$.

\section{DISCUSSION AND CONCLUSIONS}

The effect of the caudal neurosecretory system on the plasma ionic concentration is still not well established. Urophysectomy does not change the ionic and osmotic concentrations of seawater-adapted Gillichthys mirabilis (Fryer et al., 1978), Ophyocephalus maculatus (Woo and Tong, 1981) and Oreochromis mossambicus (Baldisserotto et al., 1994). Nevertheless, when freshwater-adapted O. mossambicus was transferred to brackish water, urophysectomy increased the $\mathrm{Na}^{+}, \mathrm{K}^{+}, \mathrm{Ca}^{++}$levels, as well as the plasma osmotic concentration (Baldisserotto et al., 1994). The same procedure reduced the concentrations of $\mathrm{Na}^{+}$and $\mathrm{Cl}^{-}$in the plasma of freshwater-adapted O. maculatus (Woo and Tong, 1981), and reduced $\mathrm{Na}^{+}$in Catostomus commersoni and Carassius auratus (Bern and Nishioka, 1979) but increased the plasma $\mathrm{Cl}^{-}$levels of Rhamdia sebae (Mimura, 1988). 

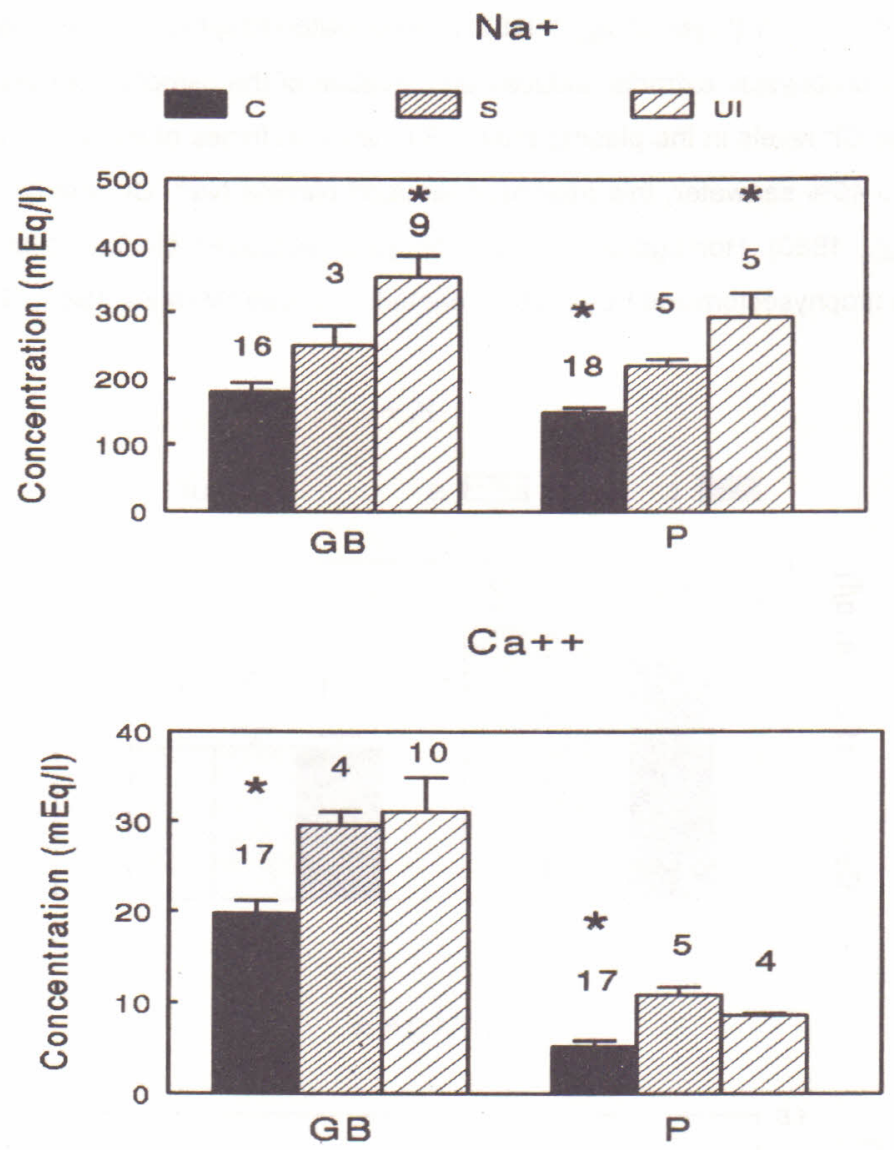

Figure 1 - lonic concentration of $\mathrm{Na}^{+}$and $\mathrm{Ca}^{++}$of the gallbladder bile (GB) and plasma (P) of Hoplias malabaricus following injection of saline (S) or UI (UI) $(500 \mathrm{ng} / \mathrm{kg})$. Control group (C). Numbers over bars represents number of fishes in each group.

statistically different of saline-injected fish $(* p<0.05)$.

The injection of urophysial extracts did not change the ionic and osmotic concentrations of fresh or seawater-adapted 0 . mossambicus when transferred to brackish water (Baldisserotto et al., 1994). The plasma ionic concentration of $G$. mirabilis adapted to $5 \%$ seawater remained unchanged with injections of urophysial extracts (Bern and Nishioka, 1979). However, these 
extracts increased the plasma $\mathrm{Na}^{+}, \mathrm{Cl}^{-}$and $\mathrm{Mg}^{++}$levels of seawater-adapted $\mathrm{G}$. mirabilis after 2-4 h (Fryer et al., 1978). In freshwater-adapted O. maculatus the injection of urophysial extracts induced an elevation of the osmotic concentration, of $\mathrm{Na}^{+}$and $\mathrm{Cl}^{-}$levels in the plasma after 3-5 h, while in fishes of the same specie, adapted to $40 \%$ seawater, this treatment reduced plasma $\mathrm{Na}^{+}, \mathrm{Cl}^{-}$and $\mathrm{K}^{+}$levels (Woo et al., 1980). Homogenates from urophysis decreased the levels of $\mathrm{Cl}^{-}$of intact and urophysectomized freshwater-adapted $R$. sebae (Mimura, 1988). The UI

$$
\mathrm{K}+
$$
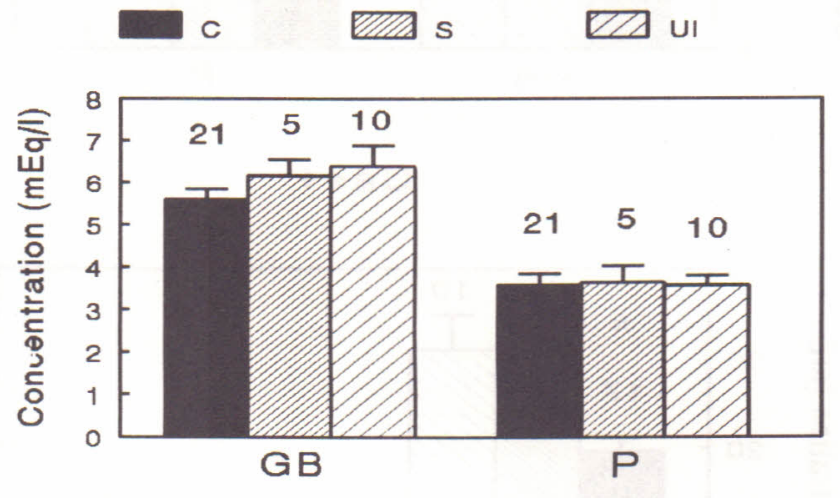

$\mathrm{Mg}++$

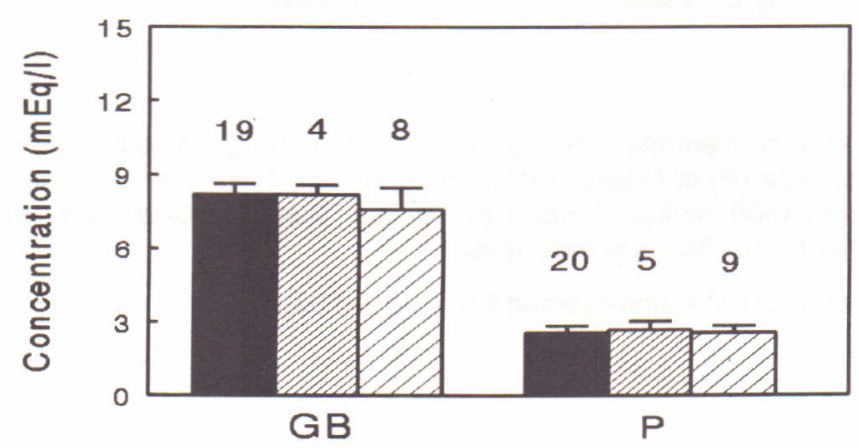

Figure 2 - lonic concentration of $\mathrm{K}^{+}$and $\mathrm{Mg}^{++}$of the gallbladder bile (GB) and plasma $(P)$ of Hoplias malabaricus following injection of saline $(\mathrm{S})$ or UI (UI) $(500 \mathrm{ng} / \mathrm{kg})$. Control group (C). Numbers over bars represents number of fishes in each group. 
injection $(500 \mathrm{ng} / \mathrm{Kg})$ inseawater-adapted G. mirabilis increases the plasma $\mathrm{Na}^{+}$, $\mathrm{Cl}^{-}$and $\mathrm{Mg}^{++}$levels (Bern and Nishioka, 1979). In H. malabaricus, the injection of $\mathrm{UI}$ increases the plasma $\mathrm{Na}^{+}$levels $2 \mathrm{~h}$ after injection, a similar result (with relation to $\mathrm{Na}^{+}$) was observed in freshwater-adapted 0 . maculatus after injection of urophysial extract (Woo et al., 1980). Since urophysectomy decreases the plasma $\mathrm{Na}^{+}$levels of freshwater-adapted Catostomus commersoni and Carassius auratus (Bern and Nishioka, 1979), it is possible that the urophysial extract or Ul injection increases the levels of this ion in the plasma of these species. The effect of the caudal neurosecretory system on the increase of plasma $\mathrm{Na}^{+}$levels of freshwateradapted teleosts is the same in the species that have been studied. Consequently, it is possible that $\mathrm{UI}$ could act on the hormonal regulation of freshwater adaptation, maintaining the plasma $\mathrm{Na}^{+}$levels. This system seems not to act on the regulation of plasma $\mathrm{K}^{+}, \mathrm{Ca}^{++}$and $\mathrm{Mg}^{++}$levels of freshwater teleosts, since neither the injection of urophysial extract in O. maculatus (Woo et al., 1980) nor UI in $H$. malabaricus changes these parameters.

Urophysial extract increases serosa-mucosa water transport, and the reabsorption of $\mathrm{K}^{+}$and $\mathrm{Mg}^{++}$on the gallbladder of freshwater-adapted Synbranchus marmoratus. In the same species, this extract inhibited reabsorption of $\mathrm{Ca}^{++}$and had no effect on $\mathrm{Na}^{+}$reabsorption (Mimura and Baldisserotto, 1989). UI also increased the water transport on the gallbladder of $H$. malabaricus, but in the opposite direction of $S$. marmoratus (reabsorption). The increase of the levels of $\mathrm{Na}+$ in the GB, induced by $\mathrm{UI}$ injection, could be a consequence of the increase of the water reabsorption by the gallbladder or due to the increase of this ion in the plasma, induced by this neurohormone. Even if $\mathrm{Ul}$ does not have an effect on $\mathrm{Na}^{+}$ transport on the gallbladder, the increase of plasma $\mathrm{Na}^{+}$levels could explain the higher levels of $\mathrm{Na}^{+}$obtained in the GB. The reabsorbative increases of water, due to $\mathrm{UI}$, could increase the plasma $\mathrm{K}^{+}, \mathrm{Ca}^{++}$, and $\mathrm{Mg}^{++}$in the $\mathrm{GB}$. However, the levels of these ion remained unchanged. Additional studies must investigate if $\mathrm{UI}$ stimulates the reabsorption of $\mathrm{K}+, \mathrm{Ca}++$, and $\mathrm{Mg}++$ by the gallbladder.

Since $\mathrm{UI}$ has altered the $\mathrm{GB} \mathrm{Na}{ }^{+}$levels and the water flow in the gallbladder, it is possible that $\mathrm{UI}$ could act in the regulation of the fish bile composition. The fact that freshwater and seawater (14\%)-adapted C. auratus have UI binding sites in the liver (Lederis et al., 1985) reinforce this hypothesis. 


\section{ACKNOWLEDGMENTS}

The authors would like to thank Mr. Manassés S. Lima (USP) for his technical assistance on ion analysis of gallbladder bile and plasma, and William Schoenau, MSc. (UFSM) for the critical reading of this article.

\section{REFERENCES}

Baldisserotto, B.; Mimura, O.M.; Farias, A.P.T.; Christensen, F. Effect of luminal $\mathrm{pH}$ on gastric motility "in vitro" of Hoplias malabaricus (TELEOSTEI). Bol. Fisiol. Anim. S. Paulo, v.14, p.13-17, 1990a.

Baldisserotto, B.; Mimura, O.M. and Salomão, L.C. Gallbladder bile and plasma ionic content of some freshwater teleosts. Bol. Fisiol. Anim. S. Paulo, v.14, p.7-11, $1990 \mathrm{~b}$.

Baldisserotto, B.; Mimura, O.M. and Salomão, L.C. Effect of $\mathrm{pH}$ on ion and water transport in the gut of the freshwater teleost, Synbranchus marmoratus. Ciência e Cultura, v.45, p.396-398, 1993.

Baldisserotto, B.; Mimura, O.M. and Salomão, L.C. Urophyseal control of plasma ionic concentration in tilapia, Oreochromis mossambicus exposed to osmotic stress. Ciência e Natura, v.16, p. 39-50, 1994.

Bern, H.A. The elusive urophysis - Twenty-five years in pursuit of caudal neurohormones. Amer. Zool., v.25, p.763-769, 1985.

Bern, H.A. and Nishioka, R.S. The caudal neurosecretory system and osmoregulation. Gunma Symp. Endocrinol., v.16, p.9-17, 1979.

Fryer, J.N.; Woo, N.Y.S.; Gunther, R.L. and Bern, H.A. Effect of urophysial homogenates on plasma ion levels in Gillichthys mirabilis (Teleostei, Gobiidae). Gen. Comp. Endocrinol., v.35, p.238-244, 1978.

Lederis, K.; Fryer, J.; Rivier, J.; MacCannell, K.L.; Kobayashi, Y.; Woo, N. and Wong, K.L. Neurohormones from fish tails. II. Actions of urotensin I in mammals and fishes. Recent Progress in Hormone Research, v.41, p.553576, 1985.

Mimura, O. M. Effects of urophyseal and terminal spinal cord homogenates on the plasma chloride level in Rhamdia sebae, a fresh water fish. Bol. Fisiol. Anim. S. Paulo, v.12, p.31-38, 1988. 
Mimura, O. M. and Baldisserotto, B. Plasma ionic and osmotic concentrations of two freshwater teleost. Prochilodus affinis and Prochilodus marggravii in different gonadal stages. Bol. Fisiol. Anim. S. Paulo, v.12, 21-30, 1988.

Mimura, O. M. and Baldisserotto, B. Water and ions isotonic transport on gall bladder in Synbranchus marmoratus (TELEOSTEI): in vitro effects of urophysial homogenates. Abstract XIth International Symposium on Comparative Endocrinology, Malaga, Spain, 1989.

Woo, N.Y.S.; Tong, W.C.M. and Chan, E.L.P. Effects of urophysial extracts on plasma electrolyte and metabolite levels in Ophiocephalus maculatus. Gen. Comp. Endocrinol., v.41, p.458-466, 1980.

Woo, N.Y.S. and Tong, W.C.M. Urophyseal control of glucose metabolism and osmoregulation in the snakehead, Ophiocephalus maculatus. In: Neurosecretion: molecules, cells, systems. D.S. Farner and K. Lederis, eds., 512-513. Plenum Press, New York, 1981. 
